\title{
Charcot-Marie-Tooth Disease Type 2A
}

National Cancer Institute

\section{Source}

National Cancer Institute. Charcot-Marie-Tooth Disease Type 2A. NCI Thesaurus. Code C134952.

A sub-type of Charcot-Marie-T ooth caused by mutation(s) in the MFN2 gene, encoding mitofusin-2. It results in peripheral axonal neuropathy. 